\title{
Rare Legumes (Fabaceae Lindl.) in Buryatia: Geographic Distribution, Eco-Coenotic Confinement, Population Diversity, and Conservation Challenges
}

\author{
Denis V. Sandanov* \\ Institute of General and Experimental Biology $S B R A S$ \\ Ulan-Ude, Russian Federation
}

Received 30.11.2017, received in revised form 14.02.2018, accepted 20.02.2018, published online 31.01.2019

\begin{abstract}
Complex studies of rare plant species allow to evaluate the status of their populations and develop an approach to their conservation. During the last years, detailed studies of rare legume species have been performed on the territory of Buryatia. They revealed new species localities, and characteristic features of species distribution and population structures. The goal of the current research is to summarize all available information including the latest data in order to develop practical recommendations for rare legume species conservation in the examined region. Populations of rare legumes and plant communities containing them were studied by traditional methods. Species distribution was analyzed using the locality database for rare vascular plants in Buryatia which contains critical information from the last edition of Red Data Book for the examined area. Distribution, ecocoenotic confinement and population structure of rare legume species in Buryatia were studied. The structure of key species populations was estimated with respect to their phytocoenotic and geographic confinement. Rare legumes populations are mostly insufficient (excluding juvenile and senile individuals), definitive, normal, and mature. Unimodal age spectra with prevalence of generative plants typical of populations from undisturbed habitats. Human impact or other exogenous factors led to formation of bimodal age spectra. The strategy for conservation of the examined species should be based on protection of their habitats and sustainable use of plant communities containing rare legumes. Further research into biological and ecological features of rare legumes, strict protection of isolated habitats, regular monitoring of populations sizes are required.
\end{abstract}

Keywords: Fabaceae, rare plant species, chorology, eco-coenotic confinement, protection of populations.

Citation: Sandanov D.V. Rare Legumes (Fabaceae Lindl.) in Buryatia: geographic distribution, eco-coenotic confinement, population diversity, and conservation challenges. J. Sib. Fed. Univ. Biol., 2020, 13(1), 81-93. DOI: 10.17516/1997-1389-0287

(C) Siberian Federal University. All rights reserved

This work is licensed under a Creative Commons Attribution-NonCommercial 4.0 International License (CC BY-NC 4.0).

* Corresponding author E-mail address: sdenis1178@mail.ru 


\title{
Редкие бобовые (Fabaceae Lindl.) Бурятии: \\ географическое распространение, \\ эколого-ценотическая приуроченность, \\ популяционное разнообразие и вопросы охраны
}

\author{
Д.В. Санданов \\ Институт общей и экспериментальной биологии СО РАН \\ Российская Федерация, Улан-Удэ
}

\begin{abstract}
Аннотация. Комплексное исследование редких видов растений позволяет провести оценку состояния их популяций и разработать меры по их охране. В последние годы проведены детальные исследования редких бобовых на территории Республики Бурятия, что позволило выявить новые местонахождения, особенности ареалов видов и характер структуры их популяций. Цель исследования - обобщение имеющейся информации с учетом современных данных для разработки конкретных рекомендаций по охране редких видов бобовых на изучаемой территории. Исследование популяций изучаемых видов и растительных сообществ с их участием осуществляли традиционными методами. Анализ распространения видов проведен на основе базы данных локалитетов редких растений, разработанной для Республики Бурятия и включающей актуальную информацию из последнего переиздания Красной книги для данной территории. Рассмотрены хорология, эколого-ценотическая приуроченность и структура популяций редких видов семейства бобовых (Fabaceae Lindl.) в Бурятии. Проведена комплексная оценка структуры популяций ключевых видов с учетом особенностей их фитоценотической и географической приуроченности. Изученные популяции редких бобовых большей частью являются неполночленными (часто отсутствуют пре- и постгенеративные особи), дефинитивными, нормальными, зрелыми. Мономодальные спектры характерны для ценопопуляций из ненарушенных и малонарушенных местообитаний с пиком на средневозрастных особях. При наличии антропогенного воздействия или других экзогенных факторов наблюдаются бимодальные онтогенетические спектры. Стратегия охраны изучаемых видов должна основываться на территориальной охране и рациональном использовании сообществ с их участием. Необходимы дальнейшие исследования по изучению биологии и экологии видов, строгая охрана изолированных местообитаний, ведение регулярного мониторинга численности в известных популяциях.
\end{abstract}

Ключевыеслова: Fabaceae, редкиерастения, хорология, эколого-ценотическая приуроченность, охрана популяций.

Цитирование: Санданов, Д.В. Редкие бобовые (Fabaceae Lindl.) Бурятии: географическое распространение, экологоценотическая приуроченность, популяционное разнообразие и вопросы охраны / Д.В. Санданов // Журн. Сиб. федер. ун-та. Биология, 2020. 13(1). C. 81-93. DOI: 10.17516/1997-1389-0287 


\section{Введение}

Изучение редких и исчезающих видов растений природной флоры России, а также отдельных ее регионов является важным звеном в комплексе мероприятий по охране растительного мира и его генофонда. Исследования редких видов растений широко проводятся по следующим направлениям: изучение таксономической принадлежности, фитоценотической и экологической приуроченности, составление региональных сводок и т.д. На первом этапе были выявлены основные местообитания редких и исчезающих видов и проведена предварительная оценка их статуса. В дальнейшем получили развитие исследования по картированию природных местообитаний, мониторингу состояния популяций в пределах естественного ареала, созданию банка данных по биологии и экологии малоизученных видов, а также разработке приемов и методов сохранения разнообразия редких и исчезающих видов. В последнее время при изучении редких видов растений все чаще используется комплексный подход с привлечением различных методов (Heywood, Iriondo, 2003 и др.).

Установление основных причин ограниченного распространения и малочисленности популяций редких видов растений также является необходимым этапом в сохранении флористического разнообразия. Основные характеристики для выделения редких видов природной флоры: узкий географический ареал, наличие вида в нескольких специфических местообитаниях, а также формирование малых изолированных популяций на протяжении всего ареала. Уникальность и специфичность флоры Бурятии тесно связана с общим генезисом и историей развития флоры Байкала. При этом в горных и степных районах Бурятии сохранились многие эндемичные и реликтовые виды растений, кото- рые на сегодня включены в категорию редких и исчезающих (Пешкова, 2001).

Семейство бобовых признано одним из крупнейших во флоре Сибири с большим числом редких видов (более 60 видов). Подробное изучение редких бобовых в течение последних лет в Республике Бурятия позволило выявить новые местонахождения, особенности ареалов видов и характер структуры популяций ключевых видов. Целью данной работы было обобщение имеющейся информации с учетом современных данных, что позволит разработать конкретные рекомендации по охране редких видов бобовых на изучаемой территории.

\section{Материалы и методы}

Распространение редких бобовых растений оценивалось на основе разработанной ГИС-базы данных (Санданов, 2016). Поясно-зональные группы и хорология редких видов приведены согласно данным Л.И. Малышева и Г.А. Пешковой (1984). При определении экологических групп растений в основном использовались данные Н. Улзийхутага (2003). Для некоторых видов сведения по экологии уточнялись на основе данных литературы и результатов собственных исследований. Латинские названия видов приведены согласно Конспекту флоры Азиатской России (2012).

Для выявления экологических факторов, отвечающих за дифференциацию растительных сообществ с участием редких видов бобовых, был применен метод непрямой (DCA) ординации (Hill, Gauch, 1980), реализованный в программе PAST 3.06 (Hammer et al., 2001). В основу работы положено 68 геоботанических описаний (с участием Astragalus galactites - 26, A. chorinensis - 33, Glycyrhiza uralensis - 9 описаний), выполненных в 2007-2015 гг. по стандартным методикам на 
площадках в $100 \mathrm{~m}^{2}$. Основные параметры популяций изучались с использованием традиционных методов (Ценопопуляции..., 1976; Одум, 1986; Zhivotosky, 2001).

\section{Результаты и обсуждение}

Анализ распространения редких бобовых на территории Бурятии показал приуроченность их местообитаний к долинам основных рек, часть местонахождений отмечена на побережье озера Байкал (рис. 1). Основные кластеры распространения видов находятся в долинах рек Селенга и Уда, в Баргузинской и Тункинской котловинах, на Восточном Саяне.

Наибольшее число местообитаний отмечено для Caragana jubata. Этот вид имеет общеазиатский ареал, встречается в высокогорьях и лесном поясе, часто образует заросли в долинах рек. Популяции вида подвержены нерегулируемой заготовке особей для лекарственных целей. Большая часть местообитаний в Бурятии охраняется на территории Тункинского национального парка и Джергинского заповедника (табл. 1).

Анализ данных показывает, что большинство редких бобовых Бурятии относится к степным видам с эндемичным типом ареала. Это отражается и на экологии видов, в основном это растения засушливых местообитаний (эуксерофиты, ксеромезофиты и мезоксерофиты).

На юге Бурятии в долинах рек Ceленга и Джида широко встречаются степные виды редких бобовых, такие как A. galactites, A. chorinensis и G. uralensis. A. galactites часто встречается в гемипсаммофитных дерновиннозлаковых степях и псаммофитно-разнотравных ильмовниках с доминированием таких видов, как Potentilla acaulis L., Artemisia frigida Willd., Thymus baicalensis Serg, Cleistogenes squarrosa (Trin.)

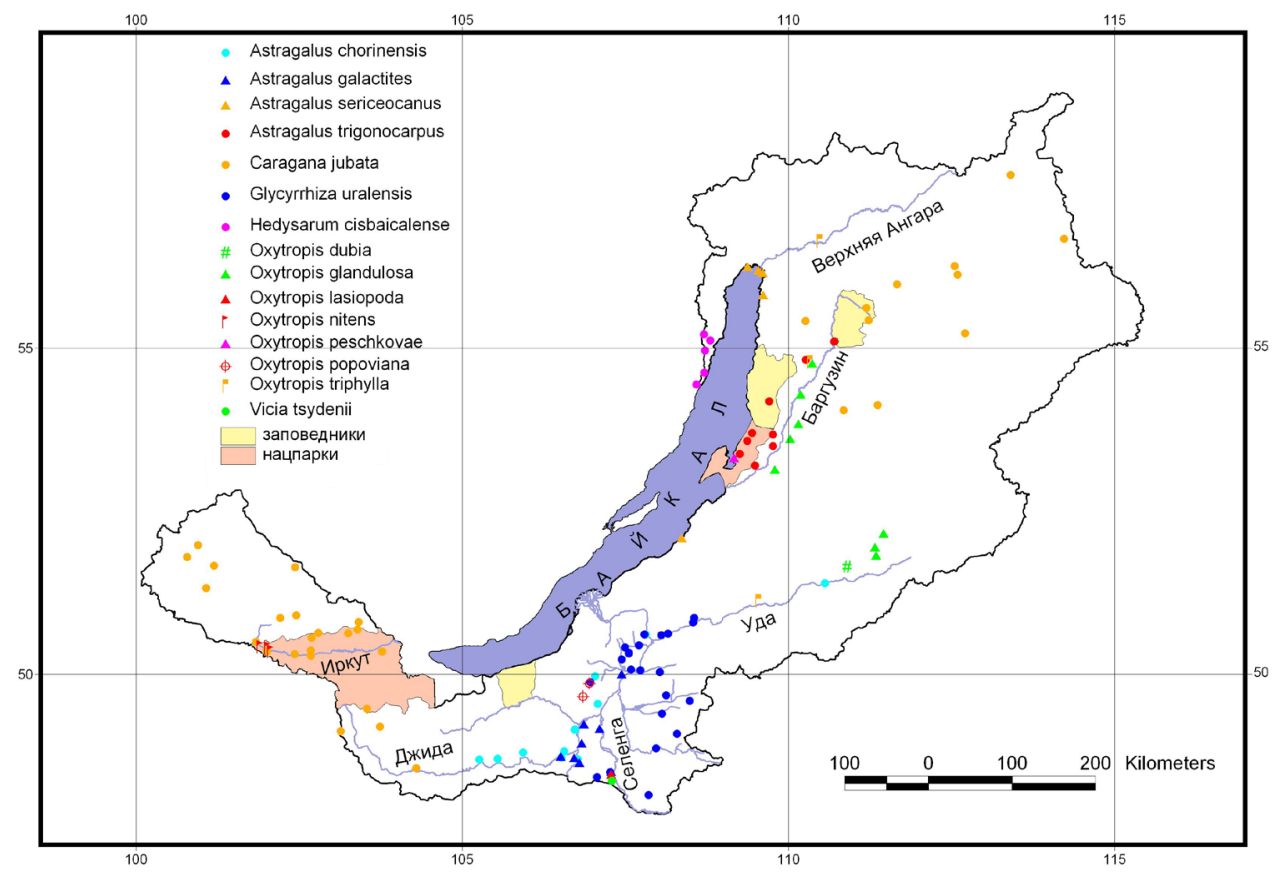

Рис. 1. Распространение редких видов сем. Fabaceae на территории Бурятии

Fig. 1. Distribution of rare species of the Fabaceae family in Buryatia 
Таблица 1. Краткая характеристика редких видов сем. Fabaceae Бурятии

Table 1. Brief characteristic of rare species of the Fabaceae family in Buryatia

\begin{tabular}{|c|c|c|c|c|c|}
\hline Название вида & Статус & ПЗГ & $\mathrm{X} Г$ & $Э Г$ & $\begin{array}{c}\text { Наличие вида на ООПТ } \\
\text { Байкальского региона }\end{array}$ \\
\hline Astragalus chorinensis Bunge & $3(\mathrm{NT})$ & $\Gamma \mathrm{C}$ & ЮC & ЭК & БЛЗ, ПНП \\
\hline Astragalus galactites Pall. & 4 (DD) & $\mathrm{CC}$ & ЮC & ЭК & Д3 \\
\hline Astragalus sericeocanus Gontsch. & $3(\mathrm{NT})$ & $\mathrm{CX}$ & ЭН & $\Pi$ & - \\
\hline $\begin{array}{l}\text { Astragalus trigonocarpus (Turcz.) } \\
\text { Bunge }\end{array}$ & $3(\mathrm{NT})$ & MM & ЭН & ЭМ & БРЗ, ЗНП \\
\hline Caragana jubata (Pall.) Poir. & $2(\mathrm{VU})$ & MM & OA & МКР & БЛ3, ДЖЗ, ТНП \\
\hline Glycyrrhiza uralensis Fisch. & $2(\mathrm{VU})$ & $\mathrm{CC}$ & OA & MK & ПНП (заносное) \\
\hline Hedysarum cisbaicalense Malysch. & $3(\mathrm{NT})$ & $\mathrm{BB}$ & ЭН & ЭМ & БЛЗ, ПНП \\
\hline Oxytropis dubia Turcz. & 4 (DD) & ЛС & ЭН & KM & - \\
\hline Oxytropis glandulosa Turcz. & $3(\mathrm{NT})$ & $\mathrm{CC}$ & ЭН & KM & - \\
\hline Oxytropis lasiopoda Bunge & $16(\mathrm{EN})$ & $\mathrm{CC}$ & ЮC & ПГ & - \\
\hline Oxytropis nitens Turcz. & $3(\mathrm{NT})$ & $\Gamma \mathrm{C}$ & ЮC & КП & ТНП \\
\hline Oxytropis peschkovae M. Pop. & $16(\mathrm{EN})$ & $\Gamma \mathrm{C}$ & ЭН & КМ & БЛЗ, ЗНП, ПНП \\
\hline Oxytropis popoviana Peschkova & $3(\mathrm{NT})$ & $\Gamma \mathrm{C}$ & ЭН & MK & БЛЗ, ПНП \\
\hline Oxytropis triphylla (Pall.) Pers. & $3(\mathrm{NT})$ & $\Gamma \mathrm{C}$ & ЭН & ЭК & БРЗ, ПНП \\
\hline Vicia tsydenii Malysch. & 1a (CR) & $\mathrm{CC}$ & ЭН & $\Pi$ & - \\
\hline
\end{tabular}

Примечание: Категории статуса редкости видов приведены согласно Красной книге Республики Бурятия (2013). Поясно-зональные группы (ПЗГ): ВВ - альпийская, ММ - монтанная, СХ - светлохвойно-лесная, ЛС - лесостепная, $\mathrm{CC}$ - собственно степная, ГС - горно-степная. Хорологические группы (ХГ): ЭН - эндемичная, ЮС-южносибирская, $\mathrm{OA} \mathrm{-} \mathrm{общеазиатская.} \mathrm{Экологические} \mathrm{группы} \mathrm{(ЭГ):} \mathrm{ЭК} \mathrm{-} \mathrm{эуксерофит,} \mathrm{МК} \mathrm{-} \mathrm{мезоксерофит,} \mathrm{КМ} \mathrm{-} \mathrm{ксеромезофит,}$ ЭМ - эумезофит, МКР - мезокриофит, ПГ - псаммогалофит, П - псаммофит, КП - ксеропетрофит. ООПТ: БРЗ Баргузинский заповедник, Б3 - Байкальский заповедник, ДЖЗ - Джергинский заповедник, БЛ3 - Байкало-Ленский заповедник, ДЗ - Даурский заповедник, ЗНП - Забайкальский национальный парк, ТНП - Тункинский национальный парк, ПНП - Прибайкальский национальный парк.

Keng, Koeleria cristata (L.) Pers. s.str. и Festuca dahurica (St.-Yves) V. Krecz. et Bobrov. Данные сообщества располагаются по выровненным подгорным шлейфам на песчаных почвах и подвержены пастбищной дигрессии. Гораздо реже вид отмечается в составе разнотравнодерновиннозлаковых степей. Однако и здесь сообщества с его участием характеризуются сильным выпасом, что индицируется высоким обилием P. acaulis, A. frigida, Carex duriuscula C.A. Меу. В травостое часто доминируют Stipa krylovii Roshev., S. baicalensis Roshev., Leymus chinensis (Trin.) Tzvelev, Th. baicalensis, C. squarrosa, Poa botryoides (Trin. ex Griseb.) Kom. Приуроченность вида к фитоценозам, где наблюдается сильный выпас, косвенно может свидетельствовать о невысокой конкурентной способности и патиентной стратегии, которая позволяет виду сохраняться в составе степных сообществ.

Сообщества с участием A. chorinensis большей частью имеют выраженный петрофитный характер. Это разнотравноселагинелловые, разнотравно-селагинелловоалтайскохамеродосовые, ленскоовсяницевые, арктогероно-тимьяновые, алтайскохамеродосово-горноколосниковые степи. Встречаются также и дигрессионные варианты этих сообществ. Помимо вышеуказанных видов в травостое часто доминируют такие виды, как Carex argunensis Turcz. ex Trev., Artemisia monostachya Bunge ex Maxim., Filifolium 
sibricium (L.) Kitam. Лимитирующими факторами численности вида выступают эндогенные (особенности биологии размножения: отсутствие вегетативного и затрудненное генеративное вследствие активного поедания семян фитофагами) и экзогенные (чрезмерная пастбищная нагрузка, особенно выпас коз и овец, весенние степные палы) (Красная..., 2013).

G. uralensis отмечается в разнотравнокрыловоковыльных, крыловоковыльно-китайсколеймусовых, разнотравно-кистевидномятликовых степях. На юге Бурятии единично встречается в степях с доминированием Stipa grandis P. Smirn.

Все изученные виды характеризовались низким обилием, в большинстве изученных сообществ их проективное покрытие составляет $<1 \%$. В некоторых случаях отмечено со- доминирование G. uralensis, что прежде всего связано с активным вегетативным разрастанием и формированием куртин. Разнообразие сообществ с участием вида (рис. 2), скорее всего, также связано с тем, что его ценокомплекс включает группы ассоциаций степных, луговых и кустарниковых сообществ (Бойков, 2005). В последние годы наблюдается сокращение площадей естественных насаждений солодки в Бурятии вследствие распашки земель и заготовки корней и корневищ в лекарственных целях. Поэтому для сохранения генофонда вида в Бурятии необходим мониторинг за состоянием популяций и организация заказников в Заиграевском, Тарбагатайском и Мухоршибирском районах (Харитонов и др., 1999). К.Ш. Шагжиев с соавторами (2014) предлагают создание на территории Селенгинской Даурии государственного степного

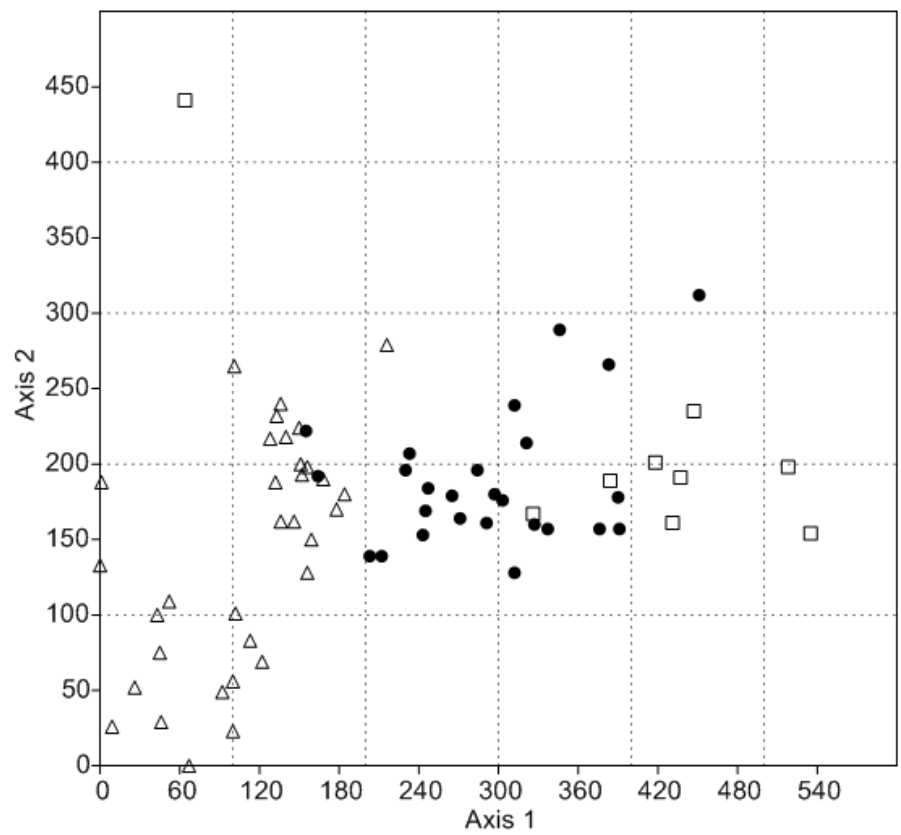

Рис. 2. DCA-ординация степных сообществ с участием редких видов сем. Fabaceae. Треугольниками обозначены сообщества с участием Astragalus chorinensis, точками - сообщества с участием Astragalus galactites, квадратами - сообщества с участием Glycyrhiza uralensis

Fig. 2. DCA-ordination of steppe communities including rare species of the Fabaceae family. Plant communities including Astragalus chorinensis, Astragalus galactites and Glycyrhiza uralensis are represented by triangles, dots and squares, respectively 
заповедника, необходимость которого обусловлена наличием на территории большого числа редких, эндемичных и реликтовых растений. Организация такого заповедника позволила бы обеспечить охраной многие редкие растения, включая и вышеуказанные виды бобовых.

Анализ геоботанических описаний с участием данных видов на основе DCAординации выявил различия в их экологии (рис. 2). Ось 1 DCA-ординации отражает изменение на градиенте увлажнения, 2-я ось связана с комплексным градиентом, где основную роль играют взаимосвязанные тренды богатства и засоленности почв и гранулометрического состава почв. Эти особенности распределения можно предположить на основе экологии изучаемых видов и их ценотической приуроченности. Проведенный анализ позволил подтвердить вклад основных факторов, ответственных за дифференциацию степных сообществ на юге Бурятии.

На севере Бурятии несколько редких видов приурочены к Баргузинскому хребту и Баргузинской котловине (рис. 1). Это такие виды, как Astragalus trigonocarpus, Oxytropis peschkovae, O. triphylla, O. glandulosa. Paнее в ходе экспедиционных исследований 2009 г. нами было обнаружено местонахождение O. triphylla на Баргузинском хребте в 4 км к западу от курорта «Алла» Курумканского района (Селютина и др., 2010). После находки вида нами были проанализированы основные гербарные коллекции России. В итоге не было выявлено упоминаний вида в этом местонахождении. Недавно в гербарии им. П.Н. Крылова Томского университета (ТК) был обнаружен образец, собранный В.И. Курбатским в 1982 г. в этом же месте. Удивительно, что сборы этого интересного вида в необычном местообитании не были ранее упомянуты в крупных флористических сводках. Данный образец находится не в лучшем состоянии (с облетевшими листочками и плодами). Повидимому, этот гербарный лист $O$. triphylla определенное время не был представлен в основном фонде, в результате чего нам не удалось с ним поработать.

Ценопопуляция в окрестностях Аллы нормальная, полночленная, зреющая, с преобладанием генеративных особей и малым числом сенильных растений. Данные мониторинга численности этой ценопопуляции с 2009 по 2016 гг. показали, что за время наблюдений в ее онтогенетической структуре не произошло значительных изменений, а плотность особей немного увеличилась (рис. 3). Увеличение плотности можно связать с тем, что при каждом учете численности нами выявлялось наличие особей на большей территории. Так, в 2012 и 2016 гг. были отмечены группы особей (в основном растения прегенеративного периода) вида в расщелинах скал, не зафиксированные при первичном мониторинге. В итоге изученная площадь популяции в 2009 г. составляла 140 кв. м и была представлена 54 особями, а в 2016 г. эти же показатели равнялись 280 кв. м и 70 особей соответственно.

В течение полевых сезонов 2014-2015 гг. было найдено еще три новых местообитания этого вида: в Заиграевском районе, в окрестностях с. Унэгэтэй, в Хоринском районе, возле с. Удинск и в Курумканском районе, в окр. с. Сахули (Чимитов и др., 2017). Эти находки позволили существенно расширить представление о современном распространении вида на территории Бурятии. В дальнейшем необходимо продолжить поиск новых местонахождений и организовать регулярный мониторинг численности в известных популяциях.

A. trigonocarpus является эндемиком Баргузинского хребта, где встречается в лесном и подгольцовом поясах, на каменистых луговых склонах и лесных опушках. Во вре- 


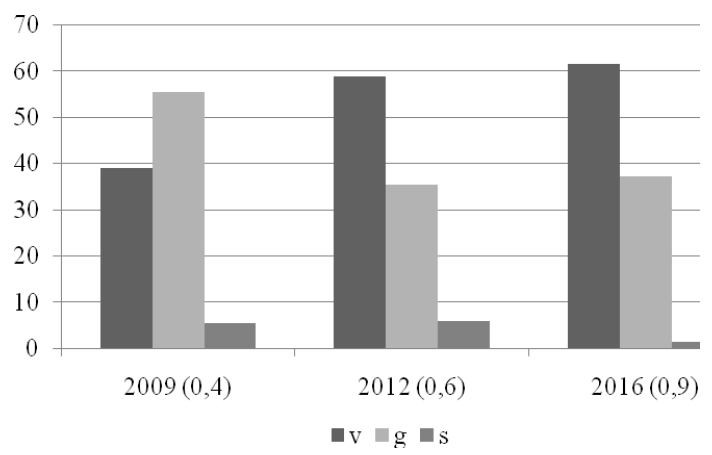

Рис. 3. Онтогенетическая структура ценопопуляций Oxytropis triphylla в разные годы исследований. По оси абсцисс указаны онтогенетические периоды (v - виргинильный, $\mathrm{g}$ - генеративный, $\mathrm{s}$ - сенильный), по оси ординат - численность особей, в \% от общего числа. После годов исследования в скобках приведена плотность ценопопуляций $O$. triphylla (особей/м²)

Fig. 3. Ontogenetic structure of Oxytropis triphylla cenopopulations in different years of study. The X-axis represents ontogenetic periods ( $\mathrm{v}$ - virginile, $\mathrm{g}$ - generative, $\mathrm{s}$ - senile), the Y-axis represents the percentage of individuals. Cenopopulation density of $O$. triphylla $\left(\mathrm{ind} . / \mathrm{m}^{2}\right.$ ) is given in brackets

мя полевых исследований 2012 г. нами были обнаружены новые местообитания вида в долинах рек Алла и Ульзыха. Анализ местообитаний вида на Баргузинском хребте показал в лесном поясе приуроченность вида к болееменее широким долинам рек на высоте более 750 м над у. м. Изученные ценопопуляции вида нормальные, неполночленные, дефинитивные, с максимумом на среднегенеративных особях. В популяциях часто наблюдается низкий процент или отсутствие ювенильных, имматурных и сенильных растений.

Интересный характер распространения имеет узколокальный эндемик озера Байкал A. sericeocanus. Основные местообитания вида находятся на северном побережье Байкала (острова Ярки и Миллионный, берег Дагарской губы). Изолированное местообитание вида в урочище «Пески» около с. Турка Прибайкальского района, по-видимому, сохранилось лишь благодаря успешной адаптации популяции в течение длительного периода времени к особым условиям обитания. Об этом свидетельствуют стабильные характеристики экологической плотности особей в ценопопуляции, а также структуры ценозов в различные годы исследования (Sandanov et al., 2014). Кариологический анализ во всех известных популяциях вида выявил, что наиболее симметричным кариотипом характеризуются особи из окрестностей с. Турка, что свидетельствует о долговременной изоляции (Konichenko et al., 2014). Эти данные также подтверждаются результатами исследования молекулярно-генетических маркеров (Selyutina et al., 2016).

Особую группу составляют виды, очень редко встречающиеся на территории Бурятии: Oxytropis dubia, O. lasiopoda, O. nitens, O. peschkovae, O. popoviana, Vicia tsydenii. Большинство из них характеризуется высоким природоохранным статусом (табл. 1). O. dubia имеет неопределенный статус, т.к. образцы вида были собраны около 170 лет назад близ с. Погроменск (современное название - с. Комсомольское Еравнинского района Бурятии). Это единственное местонахождение вида на территории России (Красная..., 2008). Поисковые работы 2014 и 2015 гг. в данном местонахождении и близлежащих окрестно- 
стях не дали результатов. Если произрастание вида на территории Бурятии в дальнейшем не будет подтверждено, то в следующем издании Красной книги Российской Федерации и Красной книги Республики Бурятия необходимо отнести данный вид к категории 0 (вероятно, исчезнувшие виды или подвиды). Схожая ситуация наблюдается с местообитанием O. lasiopoda в окрестностях с. Усть-Киран Кяхтинского района Бурятии (Флора Сибири, 1994). На современном этапе исследований не было зарегистрировано находок этого вида на территории Бурятии, имеются лишь сведения о его местонахождении в окрестностях пос. Петровский Завод Забайкальского края.

Необходимо обеспечить строгой охраной краевые популяции редкого вида $O$. nitens, находящиеся на территории Тункинского национального парка (рис. 1, табл. 1). Последними исследованиями показано, что при увеличении антропогенной нагрузки наблюдается снижение жизненности и плотности популяций, неполночленность возрастного спектра, средние и низкие показатели мощности растений (Селютина и др., 2014).

Обследование классического местообитания O. peschkovae на Крутогубском мысе Чивыркуйского залива в 2012 г. позволило подтвердить ранние сборы М.Г. Попова (Попов, Бусик, 1966). Популяция вида была представлена только семью генеративными особями. Изученные нами популяции вида в Приольхонье характеризовались невысокой плотностью (в среднем 0,7-1,3 особей/кв. м), полночленностью (но с низкой численностью особей прегенеративного периода) и максимумом на генеративных особях. В геоботанических описаниях различных степных сообществ данной территории довольно часто встречаются лишь единичные особи вида.

Местонахождения O. popoviana также в большей степени характерны для степей При- ольхонья, но в последние годы было найдено две популяции на территории Селенгинского района Бурятии. В августе 2015 г. нами было проведено изучение популяционной структуры в данных местообитаниях. Популяция в окрестностях с. Бараты характеризовалась бимодальным онтогенетическим спектром с пиками на виргинильных и среднегенеративных особях. Экологическая плотность составила 0,35 , эффективная - 0,14 особей/кв. м. Популяция возле с. Ягодное нормальная, неполночленная с максимумом на среднегенеративных особях. Показатели плотности были ниже 0,19 (экологическая) и 0,16 особей/ кв. м (эффективная).

Узколокальный эндемик V. tsydenii отмечен на территории Бурятии только в окрестностях с. Киран Кяхтинского района (единственное местонахождение вида в России). В настоящее время все ценопопуляции вида нормальные, с преобладанием средневозрастных растений, особи на южных склонах дюн характеризуются наибольшими морфометрическими параметрами (Boikov, Sutkin, 2012).

Наименее изученным редким видом бобовых на территории Бурятии является Hedysarum cisbaicalense, для которого известно несколько местонахождений на северозападной части Байкала (рис. 1). Основная часть ареала вида расположена в Иркутской области, где вид охраняется на территории Байкало-Ленского заповедника и Прибайкальского национального парка (табл. 1). На Байкальском хребте в Иркутской области встречаются фитоценозы с высоким обилием данного вида: местами в тундрах проективное покрытие почвы копеечником достигает 60 \% (Красная..., 2010). Относительная труднодоступность местообитаний и отсутствие антропогенного влияния позволяют предполагать возможность сохранения природных популяций вида. Ограниченное распростра- 
нение вида на западном побережье Байкала, по-видимому, связано с узостью его экологической амплитуды.

\section{Заключение}

Редкие виды сем. Fabaceae на территории Бурятии большей частью представлены малыми и изолированными популяциями, которые могут быть расположены в пределах дизьюнктивного ареала одной флористической или географической единицы (например, Байкальская Сибирь) или находиться в пределах узкого ареала. Изученные виды в основном представлены стержнекорневыми многоглавыми травянистыми многолетниками с поликарпическими побегами розеточного типа и относятся к каудексообразующим биоморфам моноцентрического типа. Все изученные виды относятся к долгоживущим видам растений (продолжительность жизни до 80 лет и более). Изученные популяции редких бобовых в подавляющем большинстве являются неполночленными (часто отсутствуют пре- и постгенеративные особи), дефинитивными, нормальными, зрелыми. Мономодальные спектры характерны для ценопопуляций из ненарушенных и малонарушенных местообитаний с пиком на средневозрастных особях. При наличии антропогенного воздействия или других экзогенных факторов наблюдаются бимодальные онтогенетические спектры. Высокая доля генеративных растений в большинстве изученных популяций в сочетании с длительным генеративным периодом создает возможности для их возобновления и устойчивого существования.

Среди редких бобовых Бурятии отмечается большое число эндемичных растений. В основном, это эндемики Байкальской Сибири. Большая часть изученных видов охраняется в ООПТ различного ранга на территории Байкальской Сибири, но необходимо отметить, что охваченность охраной на данном этапе недостаточна На территории Бурятии 10 видов редких эндемиков находятся за пределами ООПТ, среди которых многочисленны растения семейства Fabaceae, такие как A. sericeocanus, H. cisbaicalense, O. dubia, O. glandulosa, O. popoviana, V. tsydenii (Санданов, 2016). Сохранению редких видов бобовых Бурятии может способствовать создание новых охраняемых территорий, например степного заповедника в Селенгинской Даурии (Шагжиев и др., 2014). Также необходимо расширение границ имеющихся ООПТ для обеспечения комплексной охраны видов. При невозможности или нецелесообразности организации ООПТ на локальных участках имеет смысл проведение подробной инвентаризации местообитаний и экологии редких видов на основе выделения ключевых ботанических территорий. В этом направлении уже ведутся исследования (Холбоева и др., 2015).

Особый интерес представляет дальнейшее изучение редких видов рода Oxytropis, среди которых много эндемиков и реликтов. Большая часть этих видов встречается на территории Бурятии малочисленными и изолированными популяциями или даже несколькими особями. Численность некоторых популяций остролодок снижается вследствие антропогенного воздействия, низкого генетического разнообразия, природно-климатических изменений.

Стратегия охраны редких видов сем. Fabaceae должна основываться на территориальной охране и рациональном использовании сообществ с их участием. Также необходимы дальнейшие исследования по изучению биологии и экологии видов, строгая охрана изолированных местообитаний, ведение регулярного мониторинга численности в известных популяциях. 


\section{Благодарности / Acknowledgements}

Работа выполнена при финансовой поддержке гранта РФФИ, проект №16-04-01399 и частично в рамках государственного задания по теме № AAAA-A17-117011810036-3.

The work was supported by the RFBR grant, Project No. 16-04-01399, and was partly conducted in the framework of the State Assignment on Project No. AAAA-A17 - 117011810036-3.

\section{Список литературы / References}

Бойков Т.Г. (2005) Уникальные объекты растительного мира Центральной Сибири: разнообразие, пространственно-временное распределение, особенности и перспективы охраны. Новосибирск, Наука, 181 с. [Boikov T.G. (2005) Unique plants of Central Siberia: diversity, spacetemporal distribution, distinctive features and prospects of protection. Novosibirsk, Nauka, 181 p. (in Russian)]

Конспект флоры Азиатской России: сосудистые растения (2012) Новосибирск, Изд-во CO PAH, 640 c. [A conspectus of flora of Asian Russia: Vascular plants (2012) Novosibrisk, Siberian Branch of the Russian Academy of Sciences, 640 p. (in Russian)]

Красная книга Иркутской области (2010) Иркутск, ООО Изд-во «Время странствий», 480 c. [Red Data Book for Irkutsk region (2010) Irkutsk, Vremya stranstvyi, 480 p. (in Russian)]

Красная книга Республики Бурятия. Редкие и находящиеся под угрозой исчезновения виды животных, растений и грибов (2013) Улан-Удэ, Изд-во БНЦ СО РАН, 688 с. [Red Data Book for the Republic of Buryatia. Rare and endangered species of animals, plants, and fungi (2013) Ulan-Ude, Buryat Scientific Center of Siberian Branch of the Russian Academy of Sciences, 688 p. (in Russian)]

Красная книга Российской Федерации (растения и грибы) (2008) М., Товарищество научных изданий КМК, 855 с. [Red Data Book for the Russian Federation (plants and fungi) (2008) Moscow, Tovarishestvo nauchnykh izdanii KMK, 855 p. (in Russian)]

Малышев Л.И., Пешкова Г.А. (1984) Особенности и генезис флоры Сибири (Предбайкалье и Забайкалье). Новосибирск, Наука, 264 с. [Malyshev L.I., Peshkova G.A. Distinctive features and genesis of Siberian flora (Western and Eastern parts of Baikal) (1984) Novosibrisk, Nauka, 264 p. (in Russian)]

Одум Ю. (1986) Экология. Т. 2. М., Мир, 209 с. [Odum Е. (1986) Ecology. Vol. 2. Moscow, Mir, 209 p. (in Russian)]

Пешкова Г.А. (2001) Флорогенетический анализ степной флоры гор Южной Сибири. Новосибирск, Наука, 192 с. [Peshkova G.A. (2001) Florogenetic analysis of the steppe flora of the mountains in Southern Siberia. Novosibirisk, Nauka, 192 p. (in Russian)]

Попов М.Г., Бусик В.В. (1966) Конспект флоры побережий озера Байкал. М.-Л., Наука, 215 c. [Popov M.G., Busik V.V. (1966) A conspectus of Lake Baikal shoreline flora. Moscow, Leningrad, Nauka, 215 p. (in Russian)]

Санданов Д.В. (2016) Геоинформационный анализ распространения редких сосудистых растений на территории Бурятии. Ученые записки Забайкальского государственного университета. Серия Естественные науки, 11 (1): 38-45 [Sandanov D.V. (2016) GIS-analysis of rare vascular plants distribution on the territory of Buryatia. Scholarly Notes of Transbaikal State University. Series Natural Sciences [Uchenye zapiski Zabaikal'skogo gosudarstvennogo universiteta. Seriya Estestvennye nauki], 11 (1): 38-45 (in Russian)] 
Селютина И.Ю., Кониченко Е.С., Рупышев Ю.А. (2014) Онтогенез и онтогенетическая структура ценопопуляций редкого вида Oxytropis nitens (Fabaceae) на северной границе ареала. Ботанический журнал, 99(9): 1001-1009 [Selyutina I.Yu., Konichenko E.S., Rupishev Yu.A. (2014) Ontogeny and ontogenetic structure of coenopopulations of a rare species Oxytropis nitens (Fabaceae) on the northern limit of its range. Botanical Journal [Botanicheskii zhurnal], 99(9): 1001-1009 (in Russian)]

Селютина И.Ю., Санданов Д.В., Кониченко Е.С. (2010) Находка в Республике Бурятия Oxytropis tryphylla (Fabaceae) - эндемика западного побережья оз. Байкал. Ботанический журнал, 95(8): 1164-1170 [Selyutina I.Yu., Sandanov D.V., Konichenko E.S. (2010) The finding of endemic species Oxytropis triphylla (Fabaceae) in the Republic of Buryatia. Botanical Journal [Botanicheskii zhurnal], 95(8): 1164-1170 (in Russian)]

Улзийхутаг Н. (2003) Бобовые Монголии (таксономия, экология, география, филогения и хозяйственное значение). Улан-Батор, 588 с. [Ulziikhutag N. (2003) Legumes of Mongolia (taxonomy, ecology, geography, phylogeny, and practical importance). Ulaanbataar, 588 p. (in Russian)]

Флора Сибири. T. 9: Fabaceae (Leguminosae) (1994) Новосибирск, Наука, 280 с. [Flora of Siberia. Vol. 9: Fabaceae (Leguminosae) (1994) Novosibirsk, Nauka, 280 p. (in Russian)]

Харитонов Ю.Д., Бойков Т.Г., Швецова Н.Е., Буинова М.Г. (1999) Распространение и запасы сырья Glycyrrhiza uralensis Fisch. в Западном Забайкалье. Разнообразие растительного покрова Байкальского региона. Улан-Удэ, Изд-во Бурятского госуниверситета, с. 96-97 [Kharitonov Yu.D., Boikov T.G., Shvetsova N.E., Buinova M.G. (1999) Distribution and resources of Glycyrrhiza uralensis Fisch. in Western Transbaikalia. Diversity of vegetation cover of the Baikal region. Ulan-Ude, Buryat State University, p. 96-97]

Холбоева С.А., Банаева С.Ч., Басхаева Т.Г. (2015) Ключевая ботаническая территория «Загустайский вал» (Республика Бурятия). Вестник Бурятского госуниверситета, 4(1): 144-148 [Kholboeva S.A., Banaeva S.Ch., Baskhaeva T.G. (2015) The plant key area ridge Zagustay (Republic of Buryatia). The Buryat State University Bulletin [Vestnik Buryatskogo gosudarstvennogo universiteta], 4(1): 144-148 (in Russian)]

Ценопопулячии растений (основные понятия и структура) (1976) М., Наука, 215 с. [Cenopopulations of plants (main terms and structure) (1976) Moscow, Nauka, 215 p. (in Russian)]

Чимитов Д.Г., Иметхенова О.В., Найданов Б.Б., Санданов Д.В., Кривенко Д.А. (2017) Новые данные о распространении Oxytropis triphylla (Fabaceae) и Stipa glareosa (Poaceae) в Республике Бурятия. Растительный мир Азиатской России, 1: 10-18 [Chimitov D.G., Imetkhenova O.V., Naidanov B.B., Sandanov D.V., Krivenko D.A. (2017) New data relating to the distribution Oxytropis triphylla (Fabaceae) and Stipa glareosa (Poaceae) in the Republic of Buryatia. Plant Life of Asian Russia [Rastitel'nyj mir Aziatskoi Rossii], 1: 10-18 (in Russian)]

Шагжиев К.Ш., Намзалов Б.Б., Елаев Э.Н., Иванова О.А. (2014) О концепции организации государственного степного заповедника «Селенгинская Даурия» в Республике Бурятия. Вестник Бурятского госуниверситета, 4 (1): 37-45 [Shagzhiev K.Sh., Namsalov B.B., Elayev E.N., Ivanova O.A. (2014) On the conception of establishment a state steppe reservation "Selenginskaya Dauria" in the Republic of Buryatia. The Buryat State University Bulletin [Vestnik Buryatskogo gosudarstvennogo universiteta], 4(1): 37-45 (in Russian)] 
Boikov T.G., Sutkin A.V. (2012) Ecophytocenotic features of Vicia tsydenii Malysch. in Southern Transbaikalia. Russian Journal of Ecology, 43(5): 367-372

Hammer Ø., Harper D.A.T., Ryan P.D. (2001) PAST: Paleontological statistics software package for education and data analysis. Palaeontologia Electronica, 4 (1): art.4

Heywood V.H., Iriondo J.M. (2003) Plant conservation: old problems, new perspectives. Biological Conservation, 113(3): 321-335

Hill M.O., Gauch H.G. (1980) Detrended correspondence analysis: an improved ordination technique. Vegetatio, 42(1-3): 47-58

Konichenko E.S., Selyutina I.Yu., Dorogina O.V., Sandanov D.V. (2014) Karyotype studies endemic plant species Astragalus sericeocanus Gontsch. (Fabaceae) around Lake Baikal, Siberia. Caryologia, 67(2): 172-177

Sandanov D.V., Selyutina I.Yu., Dulepova N.A. (2014) Structure of plant communities and cenopopulations of Astragalus serioceocanus Gontsch. on the shore of Lake Baikal. Contemporary Problems of Ecology, 7(2): 237-245

Selyutina I.Yu., Konichenko E.S., Dorogina O.V., Sandanov D.V. (2016) Genetic diversity of the endangered endemic milkvetch Astragalus sericeocanus Gontsch., Fabaceae from Lake Baikal region. Biochemical Systematics and Ecology, 68: 163-169

Zhivotosky L.A. (2001) Ontogenetic states, effective density, and classification of plant populations. Russian Journal of Ecology, 32(1): 1-5 